\title{
Evidence for a role of sterol 27-hydroxylase in glucocorticoid metabolism in vivo
}

\author{
Isabelle Vögeli, Hans H Jung', Bernhard Dick, Sandra K Erickson ${ }^{2}$, Robert Escher ${ }^{3}$, \\ John W Funder ${ }^{4}$, Felix J Frey and Geneviève Escher \\ Department of Nephrology, Hypertension and Clinical Pharmacology, University Hospital Berne, CH-3010 Berne, \\ Switzerland \\ ${ }^{1}$ Department of Neurology, University Hospital Zurich, Zurich, Switzerland \\ ${ }^{2}$ Department of Medicine, University of California, San Francisco, California, USA \\ ${ }^{3}$ Department of Internal Medicine, Emmental Hospital, Burgdorf, Switzerland \\ ${ }^{4}$ Prince Henry's Institute, Clayton 3168, Victoria, Australia
}

\author{
Correspondence \\ should be addressed \\ to $\mathrm{G}$ Escher \\ Email \\ genevieve.escher@ \\ dkf.unibe.ch
}

\begin{abstract}
The intracellular availability of glucocorticoids is regulated by the enzymes

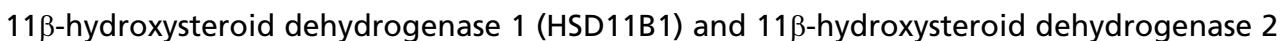
(HSD11B2). The activity of HSD11B1 is measured in the urine based on the (tetrahydrocortisol $+5 \alpha$-tetrahydrocortisol)/tetrahydrocortisone ((THF $+5 \alpha-\mathrm{THF}) / \mathrm{THE})$ ratio in humans and the (tetrahydrocorticosterone $+5 \alpha$-tetrahydrocorticosterone)/tetrahydrodehydrocorticosterone ( $(\mathrm{THB}+5 \alpha-\mathrm{THB}) / \mathrm{THA})$ ratio in mice. The cortisol/cortisone (F/E) ratio in humans and the corticosterone/11-dehydrocorticosterone (B/A) ratio in mice are markers of the activity of HSD11B2. In vitro agonist treatment of liver X receptor (LXR) downregulates the activity of HSD11B1. Sterol 27-hydroxylase (CYP27A1) catalyses the first step in the alternative pathway of bile acid synthesis by hydroxylating cholesterol to 27-hydroxycholesterol (27-OHC). Since $27-\mathrm{OHC}$ is a natural ligand for LXR, we hypothesised that CYP27A1 deficiency may up-regulate the activity of HSD11B1. In a patient with cerebrotendinous xanthomatosis carrying a loss-of-function mutation in CYP27A1, the plasma concentrations of $27-\mathrm{OHC}$ were dramatically reduced $(3.8 \mathrm{vs} 90-140 \mathrm{ng} / \mathrm{ml}$ in healthy controls) and the urinary ratios of (THF $+5 \alpha-\mathrm{THF}) / \mathrm{THE}$ and F/E were increased, demonstrating enhanced HSD11B1 and diminished HSD11B2 activities. Similarly, in Cyp27a1 knockout (KO) mice, the plasma concentrations of $27-\mathrm{OHC}$ were undetectable $(<1 \mathrm{vs} 25-120 \mathrm{ng} / \mathrm{ml}$ in Cyp27a 1 WT mice). The urinary ratio of (THB $+5 \alpha-\mathrm{THB}) / \mathrm{THA}$ was fourfold and that of B/A was twofold higher in KO mice than in their WT littermates. The (THB $+5 \alpha-T H B) / T H A$ ratio was also significantly increased in the plasma, liver and kidney of KO mice. In the liver of these mice, the increase in the concentrations of active glucocorticoids was due to increased liver weight as a consequence of Cyp27a1 deficiency. In vitro, 27-OHC acts as an inhibitor of the activity of HSD11B1. Our studies suggest that the expression of CYP27A1 modulates the concentrations of active glucocorticoids in both humans and mice and in vitro.
\end{abstract}

\section{Key Words}

- 11ß-hydroxysteroid dehydrogenase 1

- (tetrahydrocorticosterone + $5 \alpha$-tetrahydrocorticosterone)/ 11-dehydrocorticosterone ratio

- 27-hydroxycholesterol

- Cyp27a1 KO mice

- cerebrotendinous xanthomatosis
Journal of Endocrinology (2013) 219, 119-129 http://joe.endocrinology-journals.org DOI: $10.1530 / \mathrm{JOE}-13-0141$
(C) 2013 Society for Endocrinology Printed in Great Britain
Published by Bioscientifica Ltd 


\section{Introduction}

Sterol 27-hydroxylase (CYP27A1) encoded by the gene CYP27A1 is a NADPH-dependent mitochondrial enzyme, expressed in many tissues, which catalyses the hydroxylation of cholesterol to 27-hydroxycholesterol (27-OHC; Rosen et al. 1998). In the liver, CYP27A1 catalyses the first step of the alternative pathway of bile acid biosynthesis and intermediate reactions in the classical pathway initiated by CYP7A1 (Chen et al. 2005). In extrahepatic tissues, CYP27A1 plays a role in reverse cholesterol transport because its product $27-\mathrm{OHC}$ is removed and carried to the liver, where it is converted to bile acids (Weingartner et al. 2010). 27-OHC is a key regulator of cholesterol homeostasis. It is one of the natural ligands for LXR, which upon activation enhances the ABCA-1-mediated cholesterol efflux (Oram \& Lawn 2001), and is a negative feedback regulator of HMG-CoA reductase, the rate-limiting enzyme of cholesterol biosynthesis (Hall et al. 2001).

In humans, the importance of CYP27A1 in sterol homeostasis is illustrated by cerebrotendinous xanthomatosis (CTX), an autosomal recessive disease caused by a loss-of-function mutation in the CYP27A1 gene (Cali et al. 1991). The clinical features of CTX include early-onset cataracts, progressive neurological dysfunction, tendon xanthomas and, in some but not in all patients, increased incidence of premature atherosclerosis (Cali et al. 1991). Cyp27a1 gene knockout (KO) mice exhibit reduced bile acid elimination and pronounced hepatomegaly (Repa et al. 2000, Honda et al. 2001, Dubrac et al. 2005).

The intracellular concentrations of glucocorticoids are modulated by the $11 \beta$-hydroxysteroid dehydrogenase (HSD11B) enzyme. HSD11B type 1 (HSD11B1) preferentially catalyses the conversion of inactive 11-ketoglucocorticoids (cortisone (E) or 11-dehydrocorticosterone (A)) into active 11ß-hydroxyglucocorticoids (cortisol (F) or corticosterone (B)) and by this mechanism modulates cell-specific glucocorticoid action (Edwards et al. 1988, Agarwal et al. 1989, Escher et al. 1997). HSD11B type 2 (HSD11B2) inactivates endogenous F into $\mathrm{E}$ (Funder et al. 1988). In mineralocorticoid target tissues, HSD11B2 protects mineralocorticoid receptors from excessive activation by glucocorticoids (Mune et al. 1995, Atanasov et al. 2007). The regulation of $\mathrm{F}$ metabolism into tetrahydrometabolites in the liver is catalysed by the enzyme $5 \alpha$-reductase (Russell \& Wilson 1994).

Recently, evidence has accumulated that the activity of HSD11B1 contributes to glucocorticoid effects in the development of the metabolic syndrome
(Hermanowski-Vosatka et al. 2005). With the ultimate goal of treating and/or preventing the metabolic syndrome, an array of exogenous compounds inhibiting the activity of HSD11B1 have been synthesised (Boyle $\&$ Kowalski 2009), and the role of endogenous compounds including insulin, glucocorticoids, $\mathrm{TNF} \alpha$, and bile acids and their molecular mechanisms in the regulation of the expression and activity of HSD11B have been reported (Escher et al. 1997, Ackermann et al. 1999, Williams et al. 2000, Quattropani et al. 2001, Kostadinova et al. 2005, Balachandran et al. 2008, Ignatova et al. 2009). Thus, understanding the factors regulating the activity of this enzyme is of potential clinical importance.

The liver X receptor (LXR) family of nuclear receptors are ligand-activated transcription factors playing roles in the regulation of bile acid synthesis and metabolism, macrophage cholesterol efflux and lipid metabolism (Lehmann et al. 1997, Peet et al. 1998, Schwartz et al. 2000). A role for LXRs in endocrine regulation was proposed by Stulnig et al. (2002), who showed that the activation of LXRs by the agonist TO901317 downregulates the expression and activity of HSD11B1 in adipocytes, an observation confirmed in hepatocytes (Liu et al. 2006).

Based on the interplay described between LXR and HSD11B1 and between 27-OHC and LXR, in this study, we aimed to determine whether glucocorticoid homeostasis might differ in CTX patients so that the activity of HSD11B1, estimated based on urinary glucocorticoid metabolite concentrations, may be increased when compared with those in healthy controls. To further investigate the involvement of CYP27A1 in glucocorticoid metabolism, we analysed plasma, urine and tissue samples of KO mice in which 27-OHC was deficient (Rosen et al. 1998, Dubrac et al. 2005).

\section{Materials and methods}

\section{Ethics statement}

The results reported for the CTX patient are parameters commonly used in routine diagnosis in our institution. The agreement in the University Hospital stipulates that results may be used anonymously for scientific purposes.

Animal experimentation was approved by the Ethical Committee for Animal Experiments of the Veterinary Administration of the Canton of Berne, Switzerland.

Published by Bioscientifica Ltd. 
Table 1 Concentrations of plasma 27-OHC and urinary steroid metabolites in a patient with cerebrotendinous xanthomatosis (CTX). 27-OHC, F and $\mathrm{E}$ in the plasma were quantified by GC-MS. $\mathrm{F}$ and $\mathrm{E}$ and their corresponding tetrahydrometabolites THF, $5 \alpha$-THF and THE, $\alpha$-cortol, $\beta$-cortol, $\alpha$-cortolone and $\beta$-cortolone in the urine were quantified by GC-MS. Control values were as those reported in previous studies (Odermatt et al. 2001, N'Gankam et al. 2002, Burkard et al. 2004)

\begin{tabular}{|c|c|c|}
\hline & Controls & CTX \\
\hline \multicolumn{3}{|l|}{ Plasma } \\
\hline 27-OHC (ng/ml) & $90-140$ & 3.8 \\
\hline $\mathrm{F}(\mathrm{ng} / \mathrm{ml})$ & $114 \pm 22$ & 111 \\
\hline $\mathrm{E}(\mathrm{ng} / \mathrm{ml})$ & $23 \pm 7$ & ND \\
\hline \multicolumn{3}{|l|}{ Urine } \\
\hline$(\mathrm{THF}+5 \alpha-\mathrm{THF}) / \mathrm{THE}$ & $0.55-1.27$ & 1.57 \\
\hline F/E & $0.33-0.67$ & 1.36 \\
\hline Cortols/cortolones & $0.27-0.41$ & 0.53 \\
\hline THF/5 $\alpha-T H F$ & $0.70-5.29$ & 4.2 \\
\hline
\end{tabular}

$\mathrm{ND}$, not detectable (detection limit $<1 \mathrm{ng} / \mathrm{ml}$ ).

\section{Case report}

The phenotype of the CTX patient has been described previously (Bartholdi et al. 2004). Neurologically, she had progressive spastic tetraparesis and neurocognitive problems. No tendon xanthomas were found, but she reported chronic diarrhoea. A 24-h urine sample and $10 \mathrm{ml}$ of blood collected in EDTA tubes were obtained, and the concentrations of 27-OHC and urinary steroid metabolites were measured.

\section{Mouse colonies}

Cyp27a1 heterozygous (HET) males and females (a kind gift from Sandra K Erickson, Department of Medicine, University of California, San Francisco, USA) on a C57BL/6J genetic background were used to breed Cyp27a1 WT, HET and KO mice. Pups were genotyped at 3 weeks (for primers and PCR conditions, see Dubrac et al. (2005)) and weaned at the age of 4 weeks. Males used for the experiment were maintained on standard rodent chow. Details of urine, blood and tissue collection are given in Supplementary Materials and methods, see section on supplementary data given at the end of this article.

\section{Plasma and liver biochemistry}

Plasma glucose, cholesterol, triglyceride, ALT, AST and insulin and liver triglyceride concentrations were measured using commercially available kits (for details, see
Supplementary Materials and methods). The concentration of 27-OHC was measured by gas chromatography-mass spectrometry (GC-MS) as described previously (Burkard

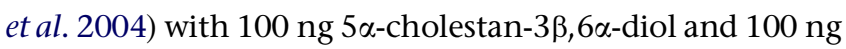
stigmasterol as standards.

\section{Analysis of steroid metabolites by GC-MS}

For both mouse and human samples, urinary steroids were extracted from $1.5 \mathrm{ml}$ of urine samples and analysed by GC-MS as described previously (Ackermann et al. 1999, Odermatt et al. 2001, Escher et al. 2009). In human urine, the concentrations of tetrahydrocortisol (THF), $5 \alpha$-tetrahydrocortisol $(5 \alpha-\mathrm{THF})$, tetrahydrocortisone (THE), F, E, $\alpha$-cortol, $\beta$-cortol, $\alpha$-cortolone and $\beta$-cortolone were measured. In mouse urine, the concentrations of tetrahydrocorticosterone (THB), 5 $\alpha$-tetrahydrocorticosterone ( $5 \alpha$-THB), tetrahydrodehydrocorticosterone (THA), B and A were measured. The concentrations of glucocorticoid metabolites in the plasma (100-1000 $\mu \mathrm{l})$ and renal and hepatic tissues (100 mg) were also measured. Following an extraction step with 10 vol of dichloromethane, steroids were extracted in the organic phase and derivatised. The detection limit was $1 \mathrm{ng} / \mathrm{ml}$ for plasma or urine and $1 \mathrm{ng} / 100 \mathrm{mg}$ for tissues.

\section{Enzymatic assays in mouse tissues}

The activities of HSD11B1 and HSD11B2 in liver and kidney homogenates were measured. Details are given in Supplementary Materials and methods.

\section{RNA extraction and real-time PCR}

Total RNA was isolated from frozen tissues using a SV Total RNA Isolation System Kit (Promega Cat No Z3100).

Table 2 Baseline characteristics of WT, HET and KO mice. Data are presented as means \pm s.E.M.

\begin{tabular}{|c|c|c|c|c|}
\hline & WT $n=10$ & HET $n=14$ & KO $n=10$ & $\boldsymbol{P}$ \\
\hline Body weight (g) & $32.1 \pm 1.7$ & $30.9 \pm 0.7$ & $30.0 \pm 1.0$ & NS \\
\hline Liver (g) & $1.47 \pm 0.16$ & $1.40 \pm 0.09$ & $2.11 \pm 0.19$ & 0.0017 \\
\hline $27-\mathrm{OHC}(\mathrm{ng} / \mathrm{ml})$ & $75 \pm 11$ & $56 \pm 7$ & $<0 . \overline{1}$ & $<0.0001$ \\
\hline $\operatorname{ALT}(\mathrm{U} / \mathrm{ml})$ & $32 \pm 7$ & $46 \pm 16$ & $115 \pm 32$ & 0.0247 \\
\hline AST (U/ml) & $141 \pm 30$ & $165 \pm 41$ & $339 \pm 85$ & 0.0402 \\
\hline Glucose $(\mathrm{mmol} / \mathrm{l})$ & $9.6 \pm 1.1$ & $8.9 \pm 0.7$ & $8.6 \pm 0.7$ & 0.0027 \\
\hline Insulin (mmol/l) & $2.7 \pm 0.3$ & $2.8 \pm 0.3$ & $3.9 \pm 0.6$ & $<0.0001$ \\
\hline $\begin{array}{l}\text { Cholesterol } \\
(\mathrm{mmol} / \mathrm{l})\end{array}$ & $2.5 \pm 0.2$ & $2.2 \pm 0.2$ & $1.6 \pm 0.1$ & 0.0247 \\
\hline $\begin{array}{l}\text { Triglycerides } \\
\text { (mmol/l) }\end{array}$ & $0.8 \pm 0.1$ & $0.8 \pm 0.1$ & $0.6 \pm 0.1$ & NS \\
\hline $\begin{array}{l}\text { Liver triglycerides } \\
\text { (ng/g liver) }\end{array}$ & $29 \pm 3$ & $28 \pm 4$ & $48 \pm 9$ & 0.0355 \\
\hline
\end{tabular}

Published by Bioscientifica Ltd. 
RT was carried out with $2 \mu \mathrm{g}$ RNA in a reaction mixture containing 100 units of SuperScript Reverse Transcriptase type II according to the manufacturer's protocol (Invitrogen Cat No 18064-022). Real-time PCR was carried out using specific TaqMan Gene Expression Assays and 18S or $\beta$-actin as the housekeeping gene, using the ABI Prism 7500 Fast Sequence Detection System (version 1.4).
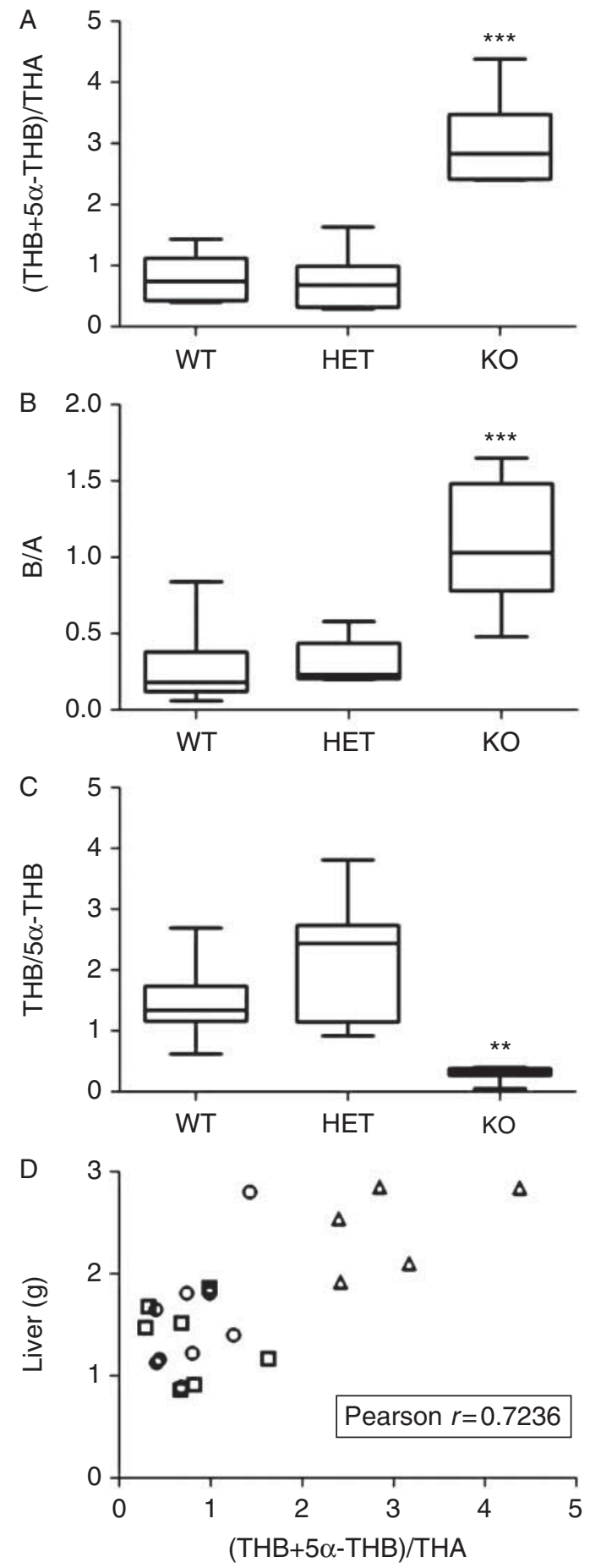

http://joe.endocrinology-journals.org DOI: 10.1530/JOE-13-0141

\section{Western blot analysis}

Liver homogenates of $20 \mu \mathrm{g}$ were separated on a $12.5 \%$ SDS-polyacrylamide gel by electrophoresis, followed by immunoblotting with anti-HSD11B1 rabbit antiserum (kind gift from C Monder) at a dilution of 1:1000 in 2\% non-fat dried milk. Bands were visualised using an enhanced chemiluminescence kit (Amersham Cat No RPN2106) and quantified by densitometry using Image J. For the internal standard, $\beta$-actin antibody (Santa-Cruz sc-47778) was used at a dilution of 1:3000 in 2\% non-fat dried milk.

\section{Effect of 27-OHC on HSD11B1 activity in vitro}

For dose-dependent inhibition studies, CHOP cells were transfected as described previously (Escher et al. 2009) with a plasmid encoding HSD11B1. The cells were harvested $48 \mathrm{~h}$ following transfection and homogenised in sucrose buffer, enzymatic assays and TLC were then carried out as described above with increasing concentrations of 27-OHC.

To measure the direct effect of the expression of CYP27A1 on the activity of HSD11B1, CHOP cells were co-transfected with a plasmid encoding HSD11B1 and CYP27A1 or pcDNA3. An enzymatic assay was carried out $48 \mathrm{~h}$ later by incubating the cells for $4 \mathrm{~h}$ at $37^{\circ} \mathrm{C}$ with $1 \mathrm{nmol}\left[{ }^{3} \mathrm{H}\right]-\mathrm{B}$. The percentage of conversion of $\mathrm{B}$ to $\mathrm{A}$ and the amounts of proteins were determined to calculate specific activity.

\section{Statistical analysis}

To determine significant differences, one-way ANOVA was used, followed by Bonferroni post hoc tests for multiple comparisons or the Kruskal-Wallis test followed by Dunn's multiple comparison tests.

\section{Figure 1}

Effect of Cyp27a1 deficiency on the excretion of urinary glucocorticoid metabolites in mice. Steroids were extracted from the urine samples of WT, HET and KO mice and analysed by GC-MS. The (THB $+5 \alpha-\mathrm{THB}) / \mathrm{THA}$ ratio increased approximately fourfold in KO mice compared with that in WT mice, indicating an increased apparent HSD11B1 reductive activity (A). The $B / A$ ratio $(B)$ doubled in $K O$ mice, indicating a reduced apparent HSD11B2 oxidase activity. The THB $/ 5 \alpha$-THB ratio, a measurement of hepatic $5 \alpha$-reductase, decreased approximately sixfold in KO mice (C). There was a correlation between the (THB $+5 \alpha-\mathrm{THB}) / \mathrm{THA}$ ratio measured in urine and liver size ( $P=0.0003)$ (circles represent WT mice, squares HET mice, and triangles KO mice) (D). Mouse urine sample number: $n=9,7,6$ for WT, HET and $\mathrm{KO}$ mice respectively. Means with whiskers (minimum and maximum) are presented. One-way ANOVA followed by Bonferroni post hoc tests for multiple comparisons was used to test statistical differences, with $* * * P<0.0001$ and $* * P<0.001$ for KO mice vs WT mice. 


\section{Results}

\section{Analysis of 27-OHC and glucocorticoid metabolites in the CTX patient}

The concentration of 27-OHC in the plasma of the CTX patient was reduced (3.8 vs 90-140 ng/ml normal range in controls) (Burkard et al. 2004), reflecting the decreased activity of CYP27A1 (Table 1). To establish whether this decreased concentration of 27-OHC was mirrored by changes in glucocorticoid ratios reflecting the activity of HSD11B1, the concentrations of glucocorticoid metabolites in the plasma and urine were determined by GC-MS. In the plasma, the concentration of $\mathrm{F}$ was in the normal range when compared with that in the controls obtained from a previous study (N'Gankam et al. 2002), whereas E was undetectable (Table 1). In the urine, increased (THF+ $5 \alpha$-THF)/THE and cortol/cortolone ratios, indicating increased reductive activity of HSD11B1, and increased $\mathrm{F} / \mathrm{E}$ ratios, reflecting diminished oxidative activity of HSD11B2, were observed. The THF/ $\alpha$-THF ratio, a measure of the activity of $5 \alpha$-reductase, remained unchanged (Table 1).

\section{Phenotype changes in KO mice}

Body weight remained unchanged, but liver size in $\mathrm{KO}$ mice was almost twice as large as that in WT or HET mice (Table 2). The weight of kidneys, spleen, lungs, testis and brain remained unchanged (data not shown). Plasma 27-OHC was undetectable in KO mice, but its concentration was not significantly reduced in HET mice (Table 2). Cyp27a1 deficiency led to an increase in the plasma concentrations of ALT and AST and to a decrease in the concentration of cholesterol and to lower glucose and higher insulin concentrations, whereas the concentrations of plasma triglycerides remained unchanged (Table 2), despite the accumulation of triglycerides in the liver of $\mathrm{KO}$ mice (Table 2).

\section{Analysis of glucocorticoid metabolites in $\mathrm{KO}$ mice}

The reductive activity of HSD11B1 assessed from the $(\mathrm{THB}+5 \alpha-\mathrm{THB}) / \mathrm{THA}$ ratio increased fourfold in the urine of KO mice compared with that in the urine of WT or HET mice (Fig. 1A). The B/A ratio increased more than twofold, indicating an apparent decrease in the oxidative activity of HSD11B2 (Fig. 1B). The THB $/ 5 \alpha$-THB ratio, a marker of the activity of $5 \alpha$-reductase, was markedly reduced in $\mathrm{KO}$ mice, indicating enhanced A-ring reduction of
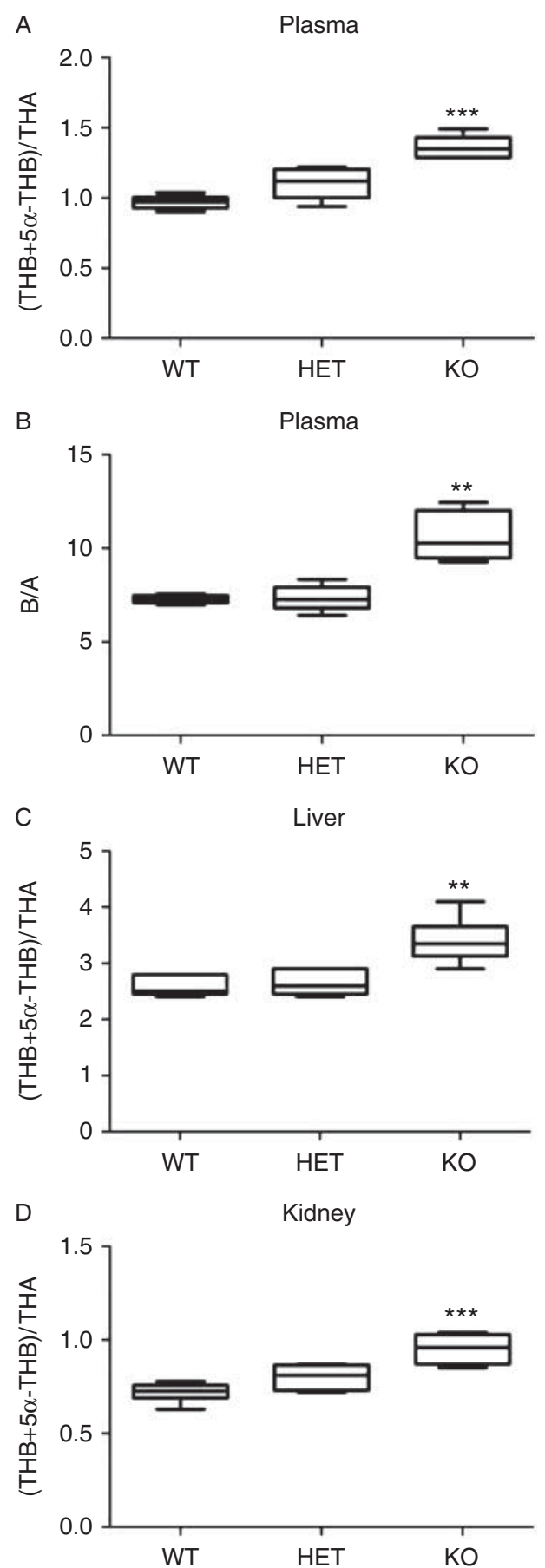

Figure 2

Effect of Cyp27a1 deficiency on plasma and tissue glucocorticoid metabolites in mice. Steroids were extracted from the plasma, liver and kidney and analysed by GC-MS. The (THB $+5 \alpha-\mathrm{THB}) / \mathrm{THA}$ and B/A ratios were increased by $\sim 50 \%$ in the plasma (A and B). The $(\mathrm{THB}+5 \alpha-\mathrm{THB}) / \mathrm{THA}$ ratio was increased by $<50 \%$ in the liver (C) and kidney (D) homogenates. Number of mouse samples: $n=5$; means with whiskers (minimum and maximum) are presented. One-way ANOVA followed by Bonferroni post hoc tests for multiple comparisons or Kruskal-Wallis $t$-tests followed by Dunn's tests were used to test statistical differences, with $* * * P<0.0001$ and $* * P<0.001$ for KO mice vs WT mice. 
THB (Fig. 1C). The total amount of steroids excreted in $24 \mathrm{~h}$ remained unchanged (data not shown), and the (THB $+5 \alpha-\mathrm{THB}) / \mathrm{THA}$ ratio was positively correlated with liver size (Fig. 1D). The (THB $+5 \alpha$-THB)/THA ratio was also significantly increased in the plasma, liver and kidney of KO mice (Fig. 2A, C and D), with no changes being observed in adrenals (data not shown). The $\mathrm{B} / \mathrm{A}$ ratio was also increased in the plasma of $\mathrm{KO}$ mice (Fig. 2B) and remained unchanged in adrenals (data not shown). Both $\mathrm{B}$ and $\mathrm{A}$ were below the detection limit in the hepatic and renal tissues.

\section{Assessment of HSD11B1 activity, protein and mRNA levels in mouse livers and kidneys}

HSD11B1 and HSD11B2 activity were measured in liver and kidney homogenates and were independent of the Cyp27a1 genotype (Fig. 3A and B). The concentration of HSD11B1 protein in liver homogenates was measured by western blot analysis, with $\beta$-actin as the internal control (Fig. 3C). The amount of HSD11B1 protein was correlated with liver size (Fig. 3D).

In hepatic tissue, the mRNA levels of Hsd11b1 were similar across all three genotypes (Fig. 4A). The mRNA levels of hexose-6-phosphate dehydrogenase $(H 6 p d)$, a known modulator of the activity of HSD11B1 (Bujalska et al. 2005, Walker et al. 2007), similarly remained unchanged (Fig. 4B), as were those of $H s d 11 b 1$ and $H s d 11 b 2$ in renal tissue of all three genotypes (Fig. 4C and D).

\section{Inhibition of HSD11B1 activity by 27-OHC in vitro}

The effect of 27-OHC on the activity of HSD11B1 was assessed in vitro in a lysate of CHOP cells transfected with a plasmid encoding HSD11B1. 27-OHC inhibited the activity of HSD11B1 in a dose-dependent manner (Fig. 5A). Similarly, the specific activity of HSD11B1 was significantly reduced in CHOP cells transfected with HSD11B1 when CYP27A1 was expressed (Fig. 5B).

\section{Discussion}

The regulation of the activities of HSD11B1 and HSD11B2 enzymes by different endogenous molecules, xenobiotics, and in various disease states has been described previously; it appears to be clinically relevant (Escher et al. 1997, 1998a,b, Fuster et al. 1998, Quattropani et al. 2001, Heiniger et al. 2003, Kostadinova et al. 2005, Ignatova et al. 2009, Konopelska et al. 2009). Herein, we report a

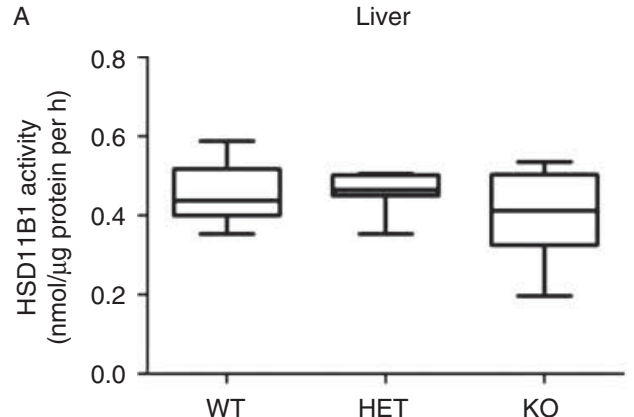

B

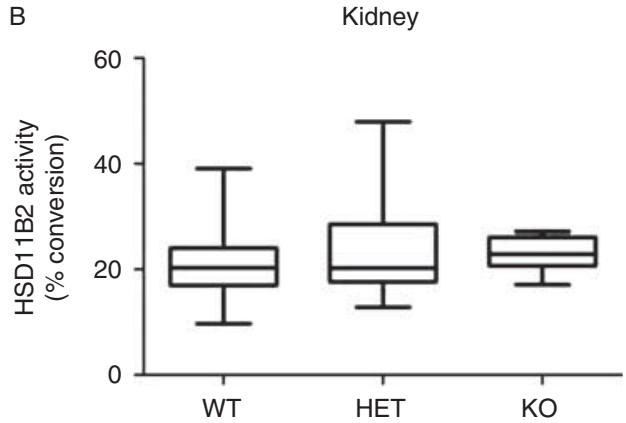

C
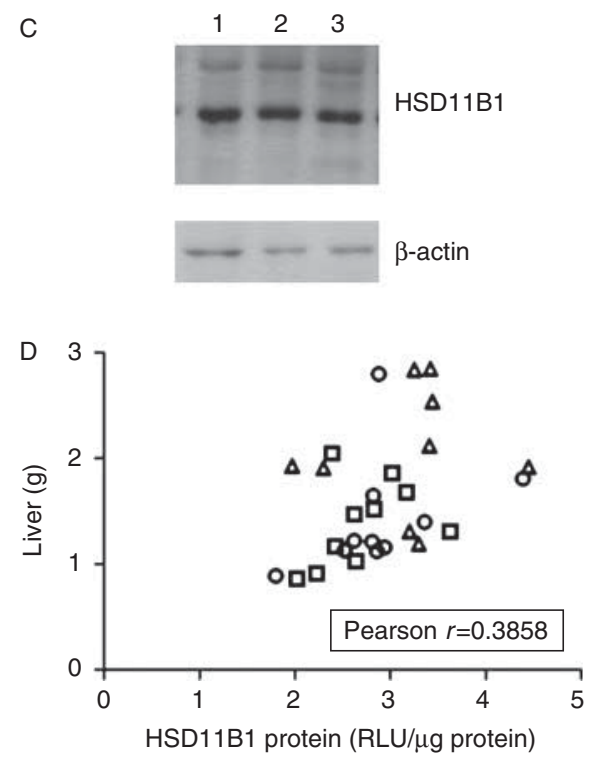

Figure 3

Effect of Cyp27a1 deficiency on HSD11B1 and HSD11B2 activities in mouse liver and kidney and HSD11B1 protein in the liver. Activity was assayed in the liver (HSD11B1) (A) and kidney (HSD11B2) (B) homogenates of WT, HET and KO mice and expressed as the percentage of conversion of substrate to product. No difference between the three groups of mice was observed. The concentration of HSD11B1 protein in liver homogenates was measured using western blot analysis, with $\beta$-actin as the internal standard. A representative blot is shown (C) with lane 1, WT; lane 2, HET; and lane 3, $\mathrm{KO}$. The relative amount of HSD11B1 protein increased with liver size $(P=0.0387)(D)$. Number of samples: $n=8,10$ and 7 for WT, HET and KO mice respectively, and values are presented as means and whiskers (minimum and maximum). Circles represent WT mice, squares HET mice, and triangles $\mathrm{KO}$ mice. 
A

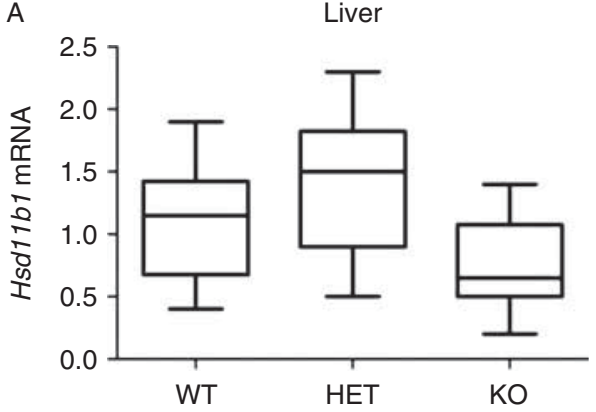

B

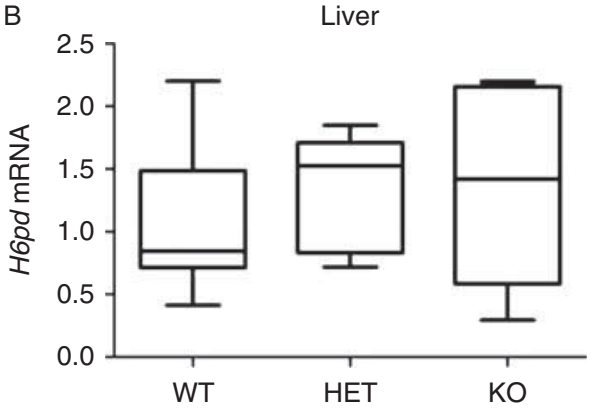

C Kidney

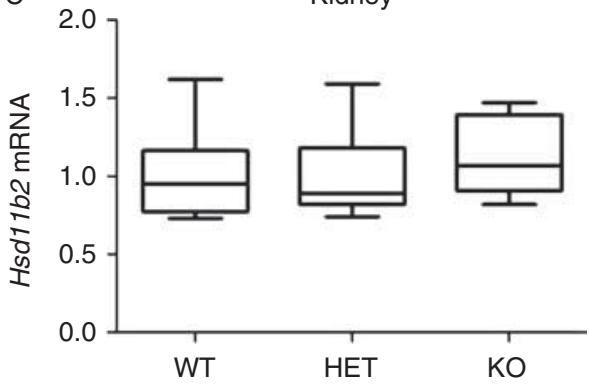

D

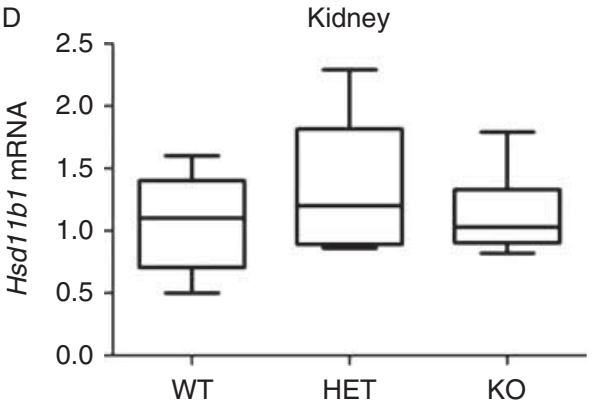

\section{Figure 4}

Quantification of hepatic and renal Hsd11b1, Hsd11b2 and H6pd mRNAs. In the liver, there was no change in Hsd11b1 (A) and H6pd (B) mRNA levels in KO mice when compared with WT littermates; there was similarly no change in $H s d 11$ b2 (C) or Hsd11b1 (D) mRNA levels in the kidney. Values are presented as means with whiskers (minimum and maximum); $n=7,13$ and 10 for WT, HET and KO mice respectively.

novel player, 27-OHC, which regulates the activity of these key enzymes, thereby determining the intracellular availability of glucocorticoids. As a confirmation of our hypothesis, and schematised in Fig. 6, we showed a diminished production of 27-OHC in the CTX patient, and this diminished production of 27-OHC enhanced the LXR-driven inhibition of HSD11B1 activity. As a result, the conversion of inactive into active glucocorticoids increased, reflecting the increased activity of HSD11B1, indicated by the absence of $\mathrm{E}$ in the plasma and elevated urinary $(\mathrm{THF}+5 \alpha$-THF)/THE and cortol/cortolone ratios. Combined with an increased $\mathrm{F} / \mathrm{E}$ ratio, an apparent indicator of a reduced activity of HSD11B2, an overall increase in the concentrations of active glucocorticoids was found in the urine of the CTX patient studied.

Similarly, in the absence of circulating 27-OHC, KO mice have an increased (THB $+5 \alpha$-THB)/THA ratio not only in the urine but also in the plasma, liver and kidney. With an increased B/A ratio in the plasma and urine,
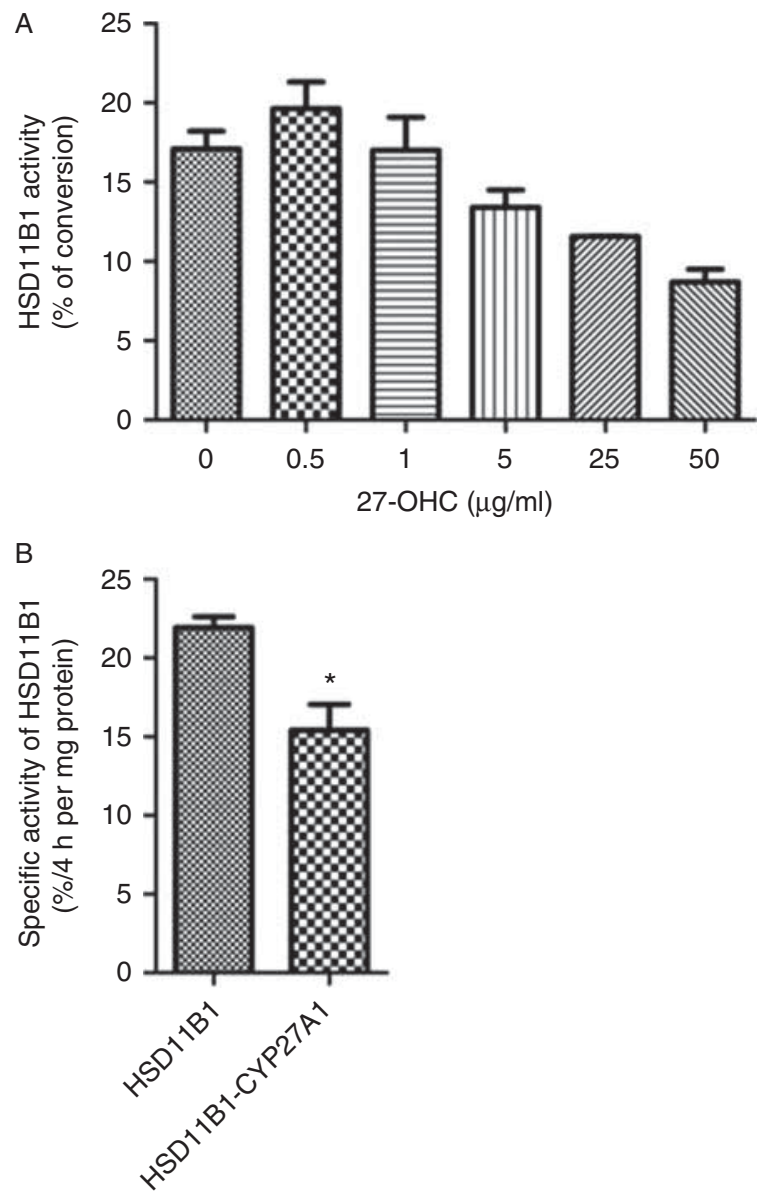

Figure 5

Effect of CYP27A1 expression on HSD11B1 activity in vitro. (A) 27-OHC inhibited the activity of HSD11B1 in a dose-dependent manner. (B) Specific activity was reduced in CHOP cells over-expressing HSD11B1 and transfected with CYP27A1 when compared with those transfected with pcDNA3. The figures show the results of representative experiments carried out in triplicates. Values are means \pm s.D. ${ }^{*}, P<0.01$ (t-test). 


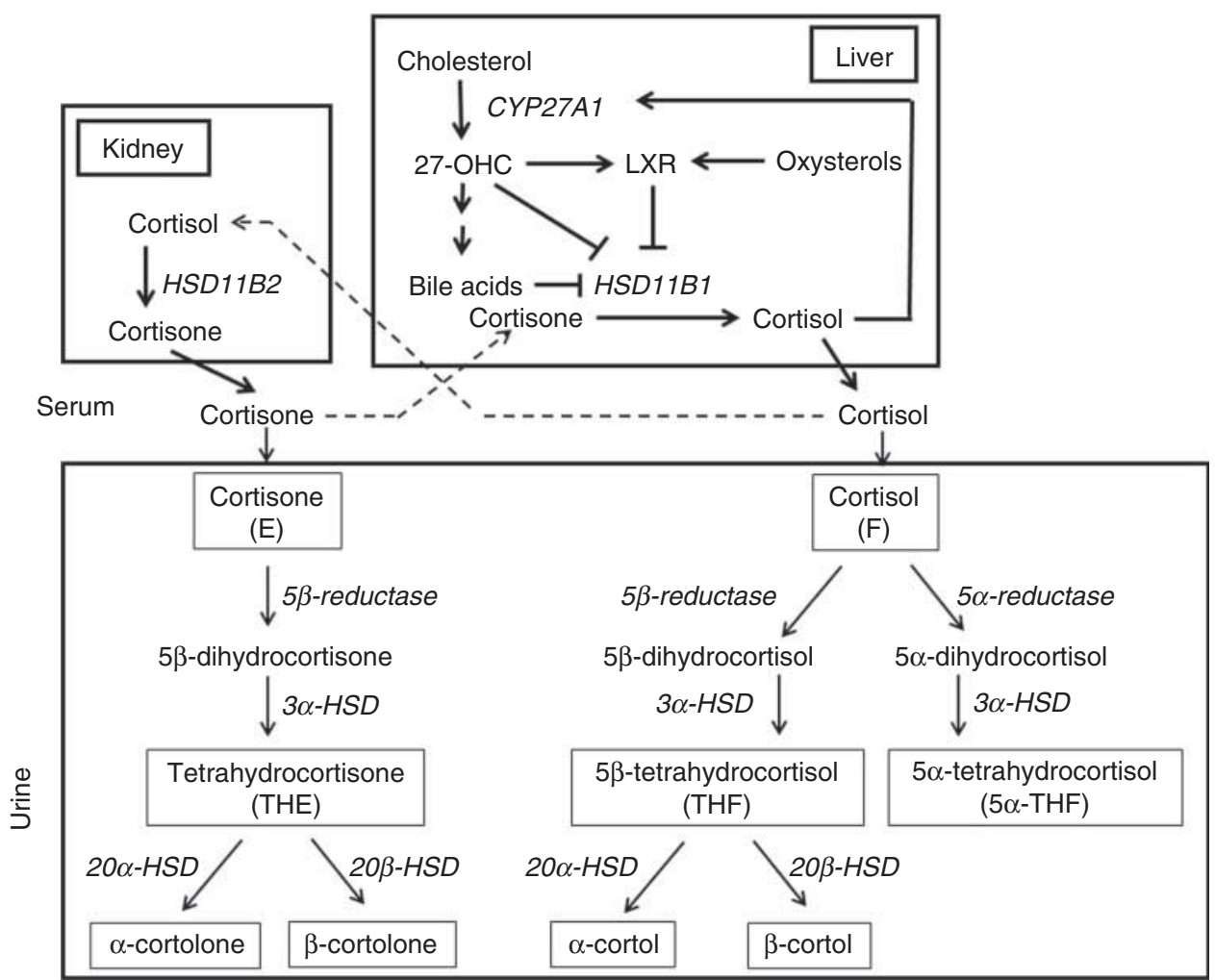

\section{Figure 6}

Tissue-specific interplay between CYP27A1 and glucocorticoid metabolism. $\mathrm{F}$ and $\mathrm{E}$ and their corresponding metabolites $5 \alpha-\mathrm{THF}$, THF and THE, and in addition cortols and cortolones, can be quantified in urine and used as markers for the local regulation of the activities of HSD11B1 and HSD11B2 enzymes. In the liver, the conversion of E to F by HSD11B1 is inhibited by

the tissues of $\mathrm{KO}$ mice are clearly exposed to increased levels of active glucocorticoids.

In vitro, 27-OHC inhibited the activity of HSD11B1 in a dose-dependent manner, and the over-expression of CYP27A1 led to a reduced activity of HSD11B1 (Fig. 5), indicating that 27-OHC itself acts as an inhibitor of the activity of HSD11B1 (Fig. 6).

Similar changes observed in the steroid ratios occur as a consequence of a reduced production of bile acids (Cali et al. 1991, Peet et al. 1998, Rosen et al. 1998, Dubrac et al. 2005). It has been shown that the removal of a biliary obstruction in patients with cholestasis with a subsequent decrease in the concentrations of bile acids in the plasma had similar impacts on the urinary ratios of (THF+

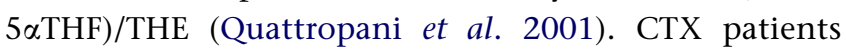
including our patient are classically treated with chenodeoxycholic acid (CDCA), a substance known to inhibit the activities of HSD11B1 and HSD11B2 (Ackermann et al. 1999). This treatment could explain the different level of both 27-OHC and bile acids. 27-OHC inhibits HSD11B1 activity directly and indirectly via LXR (Stulnig et al. 2002). Thus, the reduced activity of CYP27A1 causes an increased activity of HSD11B1, an overall effect favouring the formation of $F$ and its metabolites. The absence of CYP27A1 favours the formation of $\mathrm{F}$ and its metabolites.

increase in the urinary ratio between the CTX patient and the $\mathrm{KO}$ mice. Without treatment with bile acids, $\mathrm{KO}$ mice exhibited a fourfold increase in the (THB $+5 \alpha-\mathrm{THB}) / \mathrm{THA}$ ratio, whereas the (THF $+5 \alpha-\mathrm{THF}) / \mathrm{THE}$ ratio was only modestly increased in our CTX patient who received CDCA treatment.

Besides the activity of HSD11B1, the total levels of glucocorticoids excreted and the enzyme $5 \alpha$-reductase are also important determinants of the $\mathrm{F} / \mathrm{E}$ and $(\mathrm{THF}+5 \alpha$ THF)/THE ratios. In this study, the amount of steroids excreted in the urine was in the same range for the three groups of mice and within control values in the CTX patient (data not shown). By contrast, the activity of $5 \alpha$-reductase remained unchanged in the CTX patient, but it was decreased in $\mathrm{KO}$ mice (Table 1 and Fig. 1C), a finding that may reflect a difference between humans and mice as to the phenotypic expression of CYP27A1 depletion, i.e. hepatic steatosis in KO mice and its absence in the CTX patient. A recent study (Ahmed et al. 2012) has shown

Published by Bioscientifica Ltd. 
an increased $5 \alpha$-THF/THF ratio in patients with steatosis compared to controls, a finding in line with the reduction of the THB $/ 5 \alpha$-THB ratio in $\mathrm{KO}$ mice.

The role of endogenous glucocorticoids in the pathogenesis of the metabolic syndrome and individuals suffering from Cushing's syndrome is well established, as well as their involvement in hepatic triglyceride accumulation (Dourakis et al. 2002). In non-alcoholic fatty liver disease, one of the manifestations of the metabolic syndrome, increased clearance and decreased hepatic regeneration of cortisol have been proposed as protective mechanisms to decrease the local availability of glucocorticoids (Ahmed et al. 2012). The clinical implication of the increased availability of glucocorticoids in our CTX patient could be of interest. Given the glucocorticoidresponsive element in the promoter sequence of CYP27A1 (Tang et al. 2008), an increased concentration of cortisol might contribute substantially to the residual activity of CYP27A1.

In this study, we found that $\mathrm{KO}$ mice have increased circulating and tissue glucocorticoid concentrations (Fig. 2A) that could, at least in part, explain their hepatomegaly.

Taken together, our results indicate that the reduction of 27-OHC production by CYP27A1 and its effect on HSD11B1 activity enhance tissue concentrations of glucocorticoids and could, to a certain extent lead to the development of steatosis. The administration of 27-OHC to LDL receptor $\mathrm{KO}$ mice has been shown to reduce the accumulation of lysosomal cholesterol and hepatic inflammation in the liver (Bieghs et al. 2013). If reduced 27-OHC concentrations are found in the circulation of patients with fatty liver, enhancement of the activity of CYP27A1 might then be a viable therapeutic option.

The changes in glucocorticoid ratios observed in $\mathrm{KO}$ mice were not regulated at the level of HSD11B1 mRNA or protein in the liver (Figs $3 \mathrm{C}$ and 4 ), and the specific activities of HSD11B1 and HSD11B2 were similarly not changed (Fig. 3A and B). Thus, we might speculate that the increased $(\mathrm{THB}+5 \alpha-\mathrm{THB}) /$ THA ratio observed in the urine, plasma and liver is solely due to i) increased liver mass, ii) increased hepatic capacity to regenerate active glucocorticoids via HSD11B1, iii) decreased bile acid production, and/or iv), direct or indirect inhibition of HSD11B1 activity via the activation of LXR by 27-OHC.

In conclusion, we showed that in vivo the reduced activity of CYP27A1 increases the concentrations of active glucocorticoids in humans and mice, and that in vitro 27-OHC inhibits the activity of HSD11B1. It is the first evidence that not only xenobiotics but also enzymatic activity is involved in the regulation of HSD11B1 activity. In addition, hepatomegaly and hepatic steatosis in $\mathrm{KO}$ mice may also be a consequence of the increased availability of glucocorticoids.

\section{Supplementary data}

This is linked to the online version of the paper at http://dx.doi.org/10.1530/ JOE-13-0141.

\section{Declaration of interest}

The authors declare that there is no conflict of interest that could be perceived as prejudicing the impartiality of the research reported.

\section{Funding}

This work was supported by two grants from the Swiss National Foundation to G E (310000-109774 and 310030-122133).

\section{Author contribution statement}

IV, B D and G E contributed to the production of the results. $\mathrm{H} \mathrm{H} \mathrm{J} \mathrm{organised}$ the CTX patient and SKE provided the Cyp27a1 mouse colony. S K E, R E, J W F, F J F and G E participated in the redaction of the manuscript.

\section{Acknowledgements}

The authors thank Beatrice Blanchard and Pamela Hayoz for technical assistance.

\section{References}

Ackermann D, Vogt B, Escher G, Dick B, Reichen J, Frey BM \& Frey FJ 1999 Inhibition of $11 \beta$-hydroxysteroid dehydrogenase by bile acids in rats with cirrhosis. Hepatology 30 623-629. (doi:10.1002/hep.510300303)

Agarwal AK, Monder C, Eckstein B \& White PC 1989 Cloning and expression of rat cDNA encoding corticosteroid $11 \beta$-dehydrogenase. Journal of Biological Chemistry 264 18939-18943.

Ahmed A, Rabbitt E, Brady T, Brown C, Guest P, Bujalska IJ, Doig C, Newsome PN, Hubscher S, Elias E et al. 2012 A switch in hepatic cortisol metabolism across the spectrum of non alcoholic fatty liver disease. PLOS ONE 7 e29531. (doi:10.1371/journal.pone.0029531)

Atanasov AG, Ignatova ID, Nashev LG, Dick B, Ferrari P, Frey FJ \& Odermatt A 2007 Impaired protein stability of $11 \beta$-hydroxysteroid dehydrogenase type 2: a novel mechanism of apparent mineralocorticoid excess. Journal of the American Society of Nephrology 18 1262-1270. (doi:10.1681/ ASN.2006111235)

Balachandran A, Guan H, Sellan M, van Uum S \& Yang K 2008 Insulin and dexamethasone dynamically regulate adipocyte $11 \beta$-hydroxysteroid dehydrogenase type 1. Endocrinology 149 4069-4079. (doi:10.1210/en. 2008-0088)

Bartholdi D, Zumsteg D, Verrips A, Wevers RA, Sistermans E, Hess K \& Jung HH 2004 Spinal phenotype of cerebrotendinous xanthomatosis - a pitfall in the diagnosis of multiple sclerosis. Journal of Neurology 251 105-107. (doi:10.1007/s00415-004-0221-x)

Bieghs V, Hendrikx T, van Gorp PJ, Verheyen F, Guichot YD, Walenbergh SM, Jeurissen ML, Gijbels M, Rensen SS, Bast A et al. 2013 The cholesterol derivative 27-hydroxycholesterol reduces steatohepatitis in 
mice. Gastroenterology 144 167.e1-178.e1. (doi:10.1053/j.gastro.2012. 09.062)

Boyle CD \& Kowalski TJ 2009 11ß-Hydroxysteroid dehydrogenase type 1 inhibitors: a review of recent patents. Expert Opinion on Therapeutic Patents 19 801-825. (doi:10.1517/13543770902967658)

Bujalska IJ, Draper N, Michailidou Z, Tomlinson JW, White PC, Chapman KE, Walker EA \& Stewart PM 2005 Hexose-6-phosphate dehydrogenase confers oxo-reductase activity upon 11ß-hydroxysteroid dehydrogenase type 1. Journal of Molecular Endocrinology 34 675-684. (doi:10.1677/jme.1.01718)

Burkard I, Rentsch KM \& von Eckardstein A 2004 Determination of 24S- and 27-hydroxycholesterol in plasma by high-performance liquid chromatography-mass spectrometry. Journal of Lipid Research $\mathbf{4 5}$ 776-781. (doi:10.1194/jlr.D300036-JLR200)

Cali JJ, Hsieh CL, Francke U \& Russell DW 1991 Mutations in the bile acid biosynthetic enzyme sterol 27-hydroxylase underlie cerebrotendinous xanthomatosis. Journal of Biological Chemistry 266 7779-7783.

Chen W, Suruga K, Nishimura N, Gouda T, Lam VN \& Yokogoshi H 2005 Comparative regulation of major enzymes in the bile acid biosynthesis pathway by cholesterol, cholate and taurine in mice and rats. Life Sciences 77 746-757. (doi:10.1016/j.lfs.2004.11.036)

Dourakis SP, Sevastianos VA \& Kaliopi P 2002 Acute severe steatohepatitis related to prednisolone therapy. American Journal of Gastroenterology $\mathbf{9 7}$ 1074-1075. (doi:10.1111/j.1572-0241.2002.05644.x)

Dubrac S, Lear SR, Ananthanarayanan M, Balasubramaniyan N, Bollineni J, Shefer S, Hyogo H, Cohen DE, Blanche PJ, Krauss RM et al. 2005 Role of CYP27A in cholesterol and bile acid metabolism. Journal of Lipid Research 46 76-85. (doi:10.1194/jlr.M400219-JLR200)

Edwards CR, Stewart PM, Burt D, Brett L, McIntyre MA, Sutanto WS, de Kloet ER \& Monder C 1988 Localisation of 11ß-hydroxysteroid dehydrogenase - tissue specific protector of the mineralocorticoid receptor. Lancet 2 986-989. (doi:10.1016/S0140-6736(88)90742-8)

Escher G, Galli I, Vishwanath BS, Frey BM \& Frey FJ 1997 Tumor necrosis factor $\alpha$ and interleukin $1 \beta$ enhance the cortisone/cortisol shuttle. Journal of Experimental Medicine 186 189-198. (doi:10.1084/jem.186. 2.189)

Escher G, Nawrocki A, Staub T, Vishwanath BS, Frey BM, Reichen J \& Frey FJ $1998 a$ Down-regulation of hepatic and renal 11 $\beta$-hydroxysteroid dehydrogenase in rats with liver cirrhosis. Gastroenterology 114 175-184. (doi:10.1016/S0016-5085(98)70645-6)

Escher G, Vogt B, Beck T, Guntern D, Frey BM \& Frey FJ $1998 b$ Reduced $11 \beta$-hydroxysteroid dehydrogenase activity in the remaining kidney following nephrectomy. Endocrinology 139 1533-1539. (doi:10.1210/ en.139.4.1533)

Escher G, Vogeli I, Escher R, Tuckey RC, Erickson S, Krozowski Z \& Frey FJ 2009 Role of CYP27A1 in progesterone metabolism in vitro and in vivo. American Journal of Physiology. Endocrinology and Metabolism 297 E949-E955. (doi:10.1152/ajpendo.00298.2009)

Funder JW, Pearce PT, Smith R \& Smith AI 1988 Mineralocorticoid action: target tissue specificity is enzyme, not receptor, mediated. Science $\mathbf{2 4 2}$ 583-585. (doi:10.1126/science.2845584)

Fuster D, Escher G, Vogt B, Ackermann D, Dick B, Frey BM \& Frey FJ 1998 Furosemide inhibits 11 $\beta$-hydroxysteroid dehydrogenase type 2 . Endocrinology 139 3849-3854. (doi:10.1210/en.139.9.3849)

Hall E, Hylemon P, Vlahcevic Z, Mallonee D, Valerie K, Avadhani N \& Pandak W 2001 Overexpression of CYP27 in hepatic and extrahepatic cells: role in the regulation of cholesterol homeostasis. American Journal of Physiology. Gastrointestinal and Liver Physiology $\mathbf{2 8 1}$ G293-G301.

Heiniger CD, Kostadinova RM, Rochat MK, Serra A, Ferrari P, Dick B, Frey BM \& Frey FJ 2003 Hypoxia causes down-regulation of $11 \beta$-hydroxysteroid dehydrogenase type 2 by induction of Egr-1. FASEB Journal 17 917-919.

Hermanowski-Vosatka A, Balkovec JM, Cheng K, Chen HY, Hernandez M, Koo GC, Le Grand CB, Li Z, Metzger JM, Mundt SS et al. 2005 11ß-HSD1 inhibition ameliorates metabolic syndrome and prevents progression of atherosclerosis in mice. Journal of Experimental Medicine 202 517-527. (doi:10.1084/jem.20050119)

Honda A, Salen G, Matsuzaki Y, Batta AK, Xu G, Leitersdorf E, Tint GS, Erickson SK, Tanaka N \& Shefer S 2001 Side chain hydroxylations in bile acid biosynthesis catalyzed by CYP3A are markedly up-regulated in Cyp27 - / - mice but not in cerebrotendinous xanthomatosis. Journal of Biological Chemistry 276 34579-34585. (doi:10.1074/jbc.M103025200)

Ignatova ID, Kostadinova RM, Goldring CE, Nawrocki AR, Frey FJ \& Frey BM 2009 Tumor necrosis factor- $\alpha$ upregulates $11 \beta$-hydroxysteroid dehydrogenase type 1 expression by CCAAT/enhancer binding protein- $\beta$ in HepG 2 cells. American Journal of Physiology. Endocrinology and Metabolism 296 E367-E377. (doi:10.1152/ajpendo.90531.2008)

Konopelska S, Kienitz T, Hughes B, Pirlich M, Bauditz J, Lochs H, Strasburger CJ, Stewart PM \& Quinkler M 2009 Hepatic 11ß-HSD1 mRNA expression in fatty liver and nonalcoholic steatohepatitis. Clinical Endocrinology 70 554-560. (doi:10.1111/j.1365-2265.2008. 03358.x)

Kostadinova RM, Nawrocki AR, Frey FJ \& Frey BM 2005 Tumor necrosis factor $\alpha$ and phorbol 12-myristate-13-acetate down-regulate human $11 \beta$-hydroxysteroid dehydrogenase type 2 through p50/p50 NF-kappaB homodimers and Egr-1. FASEB Journal 19 650-652. (doi:10.1096/ fj.04-2820fje)

Lehmann JM, Kliewer SA, Moore LB, Smith-Oliver TA, Oliver BB, Su JL, Sundseth SS, Winegar DA, Blanchard DE, Spencer TA et al. 1997 Activation of the nuclear receptor LXR by oxysterols defines a new hormone response pathway. Journal of Biological Chemistry $\mathbf{2 7 2}$ 3137-3140. (doi:10.1074/jbc.272.6.3137)

Liu Y, Yan C, Wang Y, Nakagawa Y, Nerio N, Anghel A, Lutfy K \& Friedman TC 2006 Liver X receptor agonist T0901317 inhibition of glucocorticoid receptor expression in hepatocytes may contribute to the amelioration of diabetic syndrome in $\mathrm{db} / \mathrm{db}$ mice. Endocrinology 147 5061-5068. (doi:10.1210/en.2006-0243)

Mune T, Rogerson FM, Nikkila H, Agarwal AK \& White PC 1995 Human hypertension caused by mutations in the kidney isozyme of 11ß-hydroxysteroid dehydrogenase. Nature Genetics 10 394-399. (doi:10.1038/ng0895-394)

N'Gankam V, Uehlinger D, Dick B, Frey BM \& Frey FJ 2002 Increased cortisol metabolites and reduced activity of $11 \beta$-hydroxysteroid dehydrogenase in patients on hemodialysis. Kidney International 61 1859-1866. (doi:10.1046/j.1523-1755.2002.00308.x)

Odermatt A, Dick B, Arnold P, Zaehner T, Plueschke V, Deregibus MN, Repetto H, Frey BM, Frey FJ \& Ferrari P 2001 A mutation in the cofactor-binding domain of $11 \beta$-hydroxysteroid dehydrogenase type 2 associated with mineralocorticoid hypertension. Journal of Clinical Endocrinology and Metabolism 86 1247-1252. (doi:10.1210/jc.86.3.1247)

Oram JF \& Lawn RM 2001 ABCA1. The gatekeeper for eliminating excess tissue cholesterol. Journal of Lipid Research 42 1173-1179.

Peet DJ, Turley SD, Ma W, Janowski BA, Lobaccaro JM, Hammer RE \& Mangelsdorf DJ 1998 Cholesterol and bile acid metabolism are impaired in mice lacking the nuclear oxysterol receptor LXR $\alpha$. Cell 93 693-704. (doi:10.1016/S0092-8674(00)81432-4)

Quattropani C, Vogt B, Odermatt A, Dick B, Frey BM \& Frey FJ 2001 Reduced activity of $11 \beta$-hydroxysteroid dehydrogenase in patients with cholestasis. Journal of Clinical Investigation 108 1299-1305. (doi:10.1172/JCI12745)

Repa JJ, Lund EG, Horton JD, Leitersdorf E, Russell DW, Dietschy JM \& Turley SD 2000 Disruption of the sterol 27-hydroxylase gene in mice results in hepatomegaly and hypertriglyceridemia. Reversal by cholic acid feeding. Journal of Biological Chemistry 275 39685-39692. (doi:10.1074/jbc.M007653200)

Rosen H, Reshef A, Maeda N, Lippoldt A, Shpizen S, Triger L, Eggertsen G, Bjorkhem I \& Leitersdorf E 1998 Markedly reduced bile acid synthesis but maintained levels of cholesterol and vitamin D metabolites in mice with disrupted sterol 27-hydroxylase gene. Journal of Biological Chemistry 273 14805-14812. (doi:10.1074/jbc.273.24.14805) 
Russell DW \& Wilson JD 1994 Steroid $5 \alpha$-reductase: two genes/two enzymes. Annual Review of Biochemistry 63 25-61. (doi:10.1146/ annurev.bi.63.070194.000325)

Schwartz K, Lawn RM \& Wade DP 2000 ABC1 gene expression and ApoA-I-mediated cholesterol efflux are regulated by LXR. Biochemical and Biophysical Research Communications 274 794-802. (doi:10.1006/ bbrc.2000.3243)

Stulnig TM, Oppermann U, Steffensen KR, Schuster GU \& Gustafsson JA 2002 Liver X receptors downregulate $11 \beta$-hydroxysteroid dehydrogenase type 1 expression and activity. Diabetes $\mathbf{5 1} 2426-2433$. (doi:10.2337/diabetes.51.8.2426)

Tang W, Norlin M \& Wikvall K 2008 Glucocorticoid receptor-mediated upregulation of human CYP27A1, a potential anti-atherogenic enzyme. Biochimica et Biophysica Acta 1781 718-723. (doi:10.1016/j.bbalip.2008. 08.005)
Walker EA, Ahmed A, Lavery GG, Tomlinson JW, Kim SY, Cooper MS, Ride JP, Hughes BA, Shackleton CH, McKiernan P et al. 2007 11ß-Hydroxysteroid dehydrogenase type 1 regulation by intracellular glucose 6-phosphate provides evidence for a novel link between glucose metabolism and hypothalamo-pituitary-adrenal axis function. Journal of Biological Chemistry 282 27030-27036. (doi:10.1074/jbc.M704144200)

Weingartner O, Laufs U, Bohm M \& Lutjohann D 2010 An alternative pathway of reverse cholesterol transport: the oxysterol 27-hydroxycholesterol. Atherosclerosis 209 39-41. (doi:10.1016/j.atherosclerosis.2009.09.015)

Williams LJ, Lyons V, MacLeod I, Rajan V, Darlington GJ, Poli V, Seckl JR \& Chapman KE 2000 C/EBP regulates hepatic transcription of $11 \beta$-hydroxysteroid dehydrogenase type 1 . A novel mechanism for cross-talk between the C/EBP and glucocorticoid signaling pathways. Journal of Biological Chemistry 275 30232-30239. (doi:10.1074/ jbc.M001286200)

Received in final form 31 July 2013

Accepted 16 August 2013
C 2013 Society for Endocrinology Printed in Great Britain
Published by Bioscientifica Ltd. 